\title{
Tessitura intermídia: cinema e música em Manhã cinzenta, de Olney São Paulo
}

\author{
Tesitura intersemiótica: cine y música en Mañana gris, de Olney São \\ Paulo
Intermediality texture: Cinema and Music in Gray Morning, by Olney São Paulo

\author{
Antonia Cristina de Alencar Pires ${ }^{1}$ \\ Gustavo Tanus ${ }^{2}$ \\ Filipe Schettini ${ }^{3}$
}

\begin{abstract}
Resumo
A aproximação entre estética e política tem que ser pensada, nestes tempos, porque de fato elas são indissociáveis, por elaborar uma re-configuração do visível e do possível, do que é possível ser pensado. Nesse sentido, arte e política, que sempre se enlaçaram, re-afirmam modos de ver e de refletir sobre o mundo sensível (RANCIÈRE, 2005). Nesse sentido, pretendemos analisar, no filme Manhã cinzenta (1969), média-metragem do cineasta baiano Olney São Paulo, a tessitura intermidiática, partindo das definições de Irina Rajewsky (2012) e Claus Clüver (2006), com o intuito de observar como se dá a relação intermidiática entre os fios de um tecido artístico/político: a imagem e a música, respectivamente, a epiderme e o músculo (WINGSTEDT, 2005), como elementos constituidores de um corpo multimídia, responsável por resistir à ditadura civil-militar de 1964. O filme analisado pode contribuir para o rompimento com a lógica da dominação, por mostrar, em sua tessitura ficcional, os resultados das formas desiguais de poder; isso contribui para romper a linha fronteiriça desse comum, o que acreditamos ser interessante por evidenciar as tramas deste, e, com isso, os esgarçamentos no tecido da história.
\end{abstract}

Palavras-Chave: Manhã cinzenta; Olney São Paulo; Intermidialidade; Música; Cinema.

\footnotetext{
1 Doutora em Literatura Comparada; Técnica em Gestão, Proteção e Restauro do Instituto Estadual do Patrimônio Histórico e Artístico de Minas Gerais (IEPHA-MG) e cofundadora e coordenadora do grupo Moviola - estudos de literatura e cinema e outras artes; Belo Horizonte, Minas Gerais, Brasil; crisp563@ gmail.com.

${ }^{2}$ Doutorando em Estudos da Linguagem, Mestre em Teoria da Literatura e Literatura Comparada; Pesquisador do Núcleo de Estudos Interdisciplinares da Alteridade (FALE/UFMG) e Cofundador e pesquisador do Moviola grupo de pesquisas intersemióticas/intermídias: travessias entre cinema, literatura e outras áreas; Natal, Rio Grande do Norte, Brasil; gustavotcs@gmail.com.
}

${ }^{3}$ Cineasta e pesquisador. Codiretor, corroteirista e autor da trilha sonora do curta de ficção Noturno interlúdio; diretor e montador do curta documentário Arcângelo; Graduando do curso de Cinema e Audiovisual do Centro Universitário UMA e Cofundador e pesquisador do Moviola - grupo de pesquisas intersemióticas/intermídias: travessias entre cinema, literatura e outras áreas; Belo Horizonte, Minas Gerais, Brasil; filipe.schettini@outlook.com. 


\title{
Resumen
}

La aproximación entre estética y política tiene que ser pensada, en estos tiempos, porque de hecho ellas son indisociables, por elaborar una re-configuración de lo visible y lo posible, de lo que es posible ser pensado. En ese sentido, arte y política, que siempre se enlazaron, re-afirman modos de ver y de reflexionar sobre el mundo sensible. (RANCIËRE, 2005). En este sentido, pretendemos analizar, en la película Mañana gris [Manhã cinzenta] (1969), media-metraje del cineasta brasileño Olney São Paulo, la tesitura intersemiótica, partiendo de las definiciones de Irina Rajewsky (2012) y Claus Clüver (2006), buscando observar cómo la relación intermidiática entre los hilos de un tejido artístico/político: la imagen y la música, respectivamente, la epidermis y el músculo (WINGSTEDT, 2005), como elementos constituyentes de un cuerpo multimedia, responsable por resistir a la dictadura civil-militar de 1964. La película analizada puede contribuir al rompimiento con la lógica de la dominación, por mostrar, en su tesitura ficcional, los resultados de las formas desiguales de poder; que contribuye a romper la línea fronteriza de ese común, lo que creemos ser interesante por evidenciar las tramas de éste, y, con ello, los frinchos en el tejido de la historia.

Palabras claves: Gray morning; Olney São Paulo; Intermidiality; Music; Movie.

\begin{abstract}
The approximation between aesthetics and politics has to be thought in these times, because in fact they are inseparable, by elaborating a reconfiguration of the visible and the possible, of what is possible to be thought of. In this sense, art and politics, which have always become entwined, re-affirm ways of seeing and reflecting on the sensitive world. (RANCIÈRE, 2005). In this sense, we intend to analyze, in the movie Gray Morning [Manhã cinzenta] (1969), a medium-length film by the Brazilian filmmaker Olney São Paulo, the intermediality texture, from the definitions of Irina Rajewsky (2012) and Claus Clüver (2006), seeking to observe how the intermediality relationship between the threads of an artistic/political texture takes place: the image and music, respectively, epidermis and muscle (WINGSTEDT, 2005), as elements of a multimedia body responsible for resisting the civil-military dictatorship of 1964. The film analyzed can contribute to the rupture with the logic of domination, by showing, in its fictional texture, the results of the unequal forms of power; this contributes to breaking the frontier line of this common, which we believe to be interesting for evidencing the plots of this, and, with that, the fissure in the texture of history.
\end{abstract}

Keywords: Gray morning; Olney São Paulo; Intermidialidade; Music; Movie.

A Olney São Paulo, pela passagem dos 40 anos de sua morte.

\section{Introdução: primeiras linhas}

Quando as "terminações nervosas" do músculo-música e da epidermeimagem se conectam, pode-se ver uma nova criança multimídia surgir no mundo, começando a respirar. E, como se não fosse suficiente: você tenta adiantar por dois quadros a música em relação à imagem - e subitamente essa criança começa a se mexer, pulando e gritando alegremente. Esse feliz casamento entre imagem e música é um exemplo fascinante de quando o todo é alguma coisa muito maior que a soma das partes. (WINGSTEDT, 2005, p. 6).

A existência como nação exige de nós que busquemos/fomentemos reflexões sobre o que são nossas questões, sejam elas de representação ou representatividade, seja no modo como lidamos com as relações desiguais entre as pessoas, seja nos desdobramentos dessas dessimetrias. Em relação a essas questões, faz-se necessário, portanto, refletir sobre acontecimentos de um passado recente; daí pensamos, como Benjamin (1994), que nada 
deveria ser considerado perdido para a história. Nesse passado localizam-se eventos que todavia dizem respeito ao tempo presente, que foram as movimentações para a consumação da ditadura civil-militar de 1964 e, hoje, são as tentativas de desconsiderar o peso dela para a manutenção do status quo dominante e desqualificar os discursos que comprovam a violência do regime antidemocrático.

A esses movimentos soma-se a passagem do tempo que, caso não traga para a agenda nacional o debate dos excessos da ditadura, nos lança ao esquecimento de uma política de exceção (que nos ronda), que se reflete nas tantas chacinas dos tempos atuais. Dito isto, temos as grandes tarefas (éticas) de desconstrução das formas passivas de relacionamento com esse passado, contrários, portanto, a um conformismo sobre a história; e, cremos, a de elaborar táticas de rompimento com a lógica das dominações, estas que sempre buscam justificativas para os assassinatos, para os fratricídios, para a dominação dos menores, dos diferentes e para a aniquilação de seus discursos.

A aproximação entre estética e política tem que ser pensada no sentido de que elas são indissociáveis, haja vista que fazem parte da re-configuração do visível e do possível, do que é possível ser pensado. Nesse sentido, a arte e a política sempre se enlaçaram, re-afirmando determinados modos de ver e de refletir sobre o mundo sensível (RANCIÈRE, 2005). A questão passa a ser, portanto, pensar esses entrelaçamentos não apenas por um comum que pode e é partilhado e que mantém suas partes exclusivas, parte da "Partilha do sensível" (RANCIÈRE, 2005), mas também por aquilo que pode ultrapassar, em um esforço para romper com a lógica de uma partilha desigual, e buscar o rompimento da linha fronteiriça desse comum, o que acreditamos ser interessante por evidenciar as tramas deste, as frinchas e o esgarçamento no tecido.

Dito isto, nosso objetivo é realizar uma leitura do média-metragem Manhã cinzenta, do cineasta Olney São Paulo ${ }^{4}$, lançado em 1969, um dos mais significativos filmes da

\footnotetext{
${ }^{4}$ Olney Alberto São Paulo nasceu em Riachão do Jacuípe, interior da Bahia, em 7 de agosto de 1936, tendo sido criado em Feira de Santana, que são municípios vizinhos, localizados no sertão baiano. Aos 19 anos, Olney teve sua primeira participação em produção fílmica, integrando a equipe de realização e atuando como figurante das filmagens de The windrose (1955), de Alex Viany, rodado na cidade de Feira de Santana. Participou também, como assistente de direção e produção, continuísta e ator, do filme Mandacaru vermelho (1961), de Nélson Pereira dos Santos. Nesse momento, escreveu dois roteiros de documentários: O bandido negro, que é sobre uma figura lendária sertaneja, e $O$ vaqueiro das caatingas, que aborda o cotidiano dos trabalhadores que vivem desse ofício tradicional do sertão; roteiros os quais não foram realizados por falta de recursos. Participou dos seguintes filmes: Curtas-metragens: Um crime na rua (1955), em que fez roteiro, dirigiu e atuou; O profeta de Feira de Santana (1970), com roteiro, montagem, direção e coprodução; Cachoeira: documento da História (1973), também com roteiro e direção; Como nasce uma cidade (1973), roteiro, direção e produção; Teatro brasileiro I: origem e mudanças (1975), roteiro e direção; Teatro brasileiro II: novas tendências (1975), roteiro e direção;
} 
resistência à ditadura civil-militar de 1964, que também é uma espécie de metáfora da vida do próprio cineasta, afigurando-se como uma ferida em seu corpo estilhaçado pela tortura, porque tivera a ousadia de produzi-lo em plena vigência do Ato Institucional $n^{\circ} 5^{5}$.

Assim, é mister perseguir não apenas uma estética como caminho de uma apreciação/percepção sensível, mas ir ao encontro de uma ética baseada no estudo do texto - e aqui buscamos as suas relações intermidiáticas - que podem ser vistas como esses referidos modos de "partilha do sensível" (RANCIÈRE, 2005). Partimos, neste artigo, das discussões acerca das relações intermídias apontadas pelos estudos de Irina Rajewsky (2012) e Claus Clüver (2006), em que atravessamos as noções de intermídia como uma menção referencial realizada no interior de um texto a um outro texto que partilhe de outro sistema semiótico, e mesmo a sua capacidade relacional como possibilidade. Dito isto, interessa-nos, neste artigo, observar o encontro entre imagem e música em Manhã cinzenta, buscando compreender tal encontro como a relação que se verifica entre a epiderme e o músculo que constituem um corpo fílmico, esse corpo-filme gestado, esse "ser multimídia" de que nos fala Wingstedt. Nosso interesse é tanto pelo fenômeno possível de ser observado no procedimento de trânsito entre esses sistemas, o que é chamado de transposição intersemiótica, quanto pelos modos de (com)partilhamento dialógico de suas semelhanças e diferenças, dentro de um espaço do filme, onde acontece a intersemiose.

Com efeito, o trânsito entre artes distintas operado por Olney São Paulo em Manhã cinzenta, que resulta numa tessitura intermídia, salienta uma relação na qual a música não é mero pano de fundo para as cenas do filme, mas parte dessas cenas, uma espécie de metáfora sonora que dialoga com a imagem visual, intencionando reiterar a questão fulcral do médiametragem, que é o desvelamento da situação vivida na América Latina naquele momento, mergulhada nas trevas das ditaduras e no aniquilamento dos direitos civis.

\section{Trânsitos possíveis: algumas considerações sobre a teoria intermídias/interartes}

Sob o ditame do rude Almajesto: sinais de chuva (1976), roteiro e direção; A última feira livre (1976) direção. Médias-metragens: Manhã cinzenta (1969), roteiro, direção e produção; Pinto vem aí (1976), roteiro e direção; Dia de Erê (1978), roteiro e direção. Longas-metragens: Grito da terra (1964), roteiro e direção; O forte (1974), roteiro e direção; Ciganos do nordeste (1976), roteiro, direção e produção; e O Amuleto de Ogum (1974). Faleceu no Rio de Janeiro, em 15 de fevereiro de 1978, alguns anos após as torturas sofridas durante sua prisão por causa do filme analisado neste artigo.

${ }^{5}$ Este ato permitiu a censura prévia às produções culturais e à mídia, o toque de recolher, o ataque desigual aos não cooperativos ao golpe e a perda das garantias individuais, com a suspensão do habeas corpus, o que possibilitava a prisão injusta, arbitrária e violenta e também a coação dos cidadãos que os golpistas de então julgassem serem contrários ao regime imposto. 
A interação entre textualidades, a "interação semiótica" (SILVA, 1986, p. 625), é importante para a consideração de aspectos da poética de Olney São Paulo. Dessa interação referimo-nos aos encontros entre textualidades pertencentes a sistemas semióticos distintos, como o cinema e a música, que no filme objeto deste artigo revela-nos como "o todo pode ser alguma coisa muito maior que a soma das partes" (WINGSTEDT, 2005, p. 6 apud BAPTISTA, 2007, p. 9). Para isso, retomamos os estudos interartes - intermidialidade, de Irina Rajewsky (2012), e intersemióticos, de Claus Clüver (2006) - importantes para a interpretação dos trânsitos e dissoluções de fronteiras nos/dos textos olneyanos.

Esse fenômeno pressupõe que existam fronteiras tangíveis entre mídias individuais, bem como especificidades e diferenças midiáticas. Em tipificação dos modos de interação entre as mídias, a intermidialidade acontece com cruzamento entre as fronteiras de distintas manifestações artísticas. Irina Rajewsky (2012, p. 58) desenha três grupos de fenômenos: 1. A transposição midiática, operada pelas adaptações cinematográficas e romantizações (transformação do filme em romance); 2. A combinação de mídias, como "ópera, filme, teatro, performance, manuscritos com iluminuras, instalações em computador ou de arte sonora, quadrinhos" (RAJEWSKY, 2012, p. 24); e 3. A intermidialidade no sentido do processo de referenciação, em que uma obra faz menção a outra, por exemplo, por dentro de um texto literário existir uma referência a um filme, ou neste a uma pintura, etc. A primeira relaciona-se à gênese, sendo orientada ao processo de produção. Ela pode ser observada na transposição realizada na transformação do conto em filme.

Nesse caso, a qualidade intermidiática - o critério de cruzamento de fronteiras midiáticas - relaciona-se à maneira com que uma configuração midiática vem ao mundo, ou seja, relaciona-se à transformação de uma configuração midiática definida (um texto, um filme, etc.) ou de seu substrato noutra mídia. (RAJEWSKI, 2012, p. 59).

Da combinação, Irina Rajewsky trata da conjugação entre mídias, em uma combinação que, em uma perspectiva histórica, torna-se nova forma. No terceiro grupo, Rajewsky coloca as menções que uma obra faz a outra, quando a relação intermidiática dá-se não apenas no processo de formação da mídia, mas "na significação e/ou estrutura de uma dada entidade semiótica” (WOLF, 2005, p. 253 apud RAJEWSKI, 2012, p. 59).

O fenômeno da intermidialidade em si extrapola, segundo Clüver, o que se define comumente como artes: 
Música, Literatura, Dança, Pintura e demais Artes Plásticas, Arquitetura, bem como formas mistas, como Ópera, Teatro e Cinema e também o que definimos como mídias, o que inclui tanto as mídias impressas quanto o Cinema, a Televisão, o Rádio, o Vídeo, bem como as várias mídias eletrônicas e digitais surgidas mais recentemente. (CLÜVER, 2006, p. 1819).

Para ele - que prefere o uso "textos intersemióticos" a "textos intermídias", porque nem todo sistema de signos é essencialmente uma mídia - “o texto intersemiótico [...] recorre a dois ou mais sistemas de signos e/ou mídias de uma forma tal que os aspectos visuais e/ou musicais, verbais, cinéticos e performativos dos seus signos se tornam inseparáveis e indissociáveis" (CLÜVER, 2006, p. 20). O autor ainda atenta para "intermidialidade", um conceito dado por Helbig, em importante livro intitulado Intermidialidade: teoria e prática de uma área de estudos interdisciplinares ${ }^{6}$. Este pode ser pensado nestas formas possíveis de relação: 1. Relações entre mídias em geral (relações intermidiáticas); 2. Transposições de uma mídia para outra (transposições intermidiáticas ou intersemióticas); 3. União (fusão) de mídias, que são os textos multimídias e mixmídias (CLÜVER, 2006, p. 24). Vemos a diferença entre as possibilidades do termo. Rajewsky definiu a intermidialidade a partir da: transposição, combinação e referenciação. Já Clüver, retomando Helbig, definiu como: relações intermídias, transposições intermidiáticas e fusão de mídias.

Em relação a essas definições vistas, nos é interessante pensar a intermidialidade como um trânsito modos de partilha e de relacionamento, esse que, segundo Wingstedt (2005), forma o "ser multimídia", no nosso caso o filme de Olney, gestado pela relação entre a epiderme e o músculo, esse corpo composto, respectivamente, pela imagem e pela música.

\section{Encontros, proximidades: análise da intermidialidade imagem/música em Manhã cinzenta}

\subsection{A epiderme-imagem}

Em agosto de 1969, Olney São Paulo trazia à luz um dos filmes mais importantes e significativos da história do cinema do Brasil: o média-metragem Manhã cinzenta. O filme foi vetado pelo Serviço de Censura de Diversões Públicas para exibição sob a alegação de ser "altamente subversivo e incitar o povo contra os dirigentes", no caso, os militares que tomaram o poder no país, em 1964, após um golpe apoiado por segmentos da sociedade civil

\footnotetext{
6 Título traduzido do original, edição alemã: Intermedialität: Theorie und Praxis eines interdisziplinären Forschungsgebiets. Berlim: Erich Schmidt, 1998.
} 
(elite econômica e parte da classe média). Em contraposição ao argumento da Censura, Olney declarava ao jornal Última hora, em setembro daquele ano, que seu média-metragem era "um canto desesperado ao amor e à liberdade", apontando o profundo humanismo que circunda seu filme.

Em 1968, ano de grande turbulência e intensa efervescência cultural no mundo e no Brasil, a ditadura civil-militar brasileira tornara-se ainda mais repressiva, com a decretação dos Atos Institucionais, que legislavam acima da Constituição, e com a vigilância intensa sobre tudo e todos. Em razão disso, intensificam-se os protestos de rua na cidade do Rio de Janeiro. Desde março daquele ano, quando foi assassinado pela polícia o estudante secundarista Edson Luís de Lima Souto, no Calabouço, restaurante frequentado por estudantes carentes, até 13 de dezembro, dia em que foi decretado o Ato Institucional $\mathrm{N}^{\mathrm{o}} 5$ (AI-5), as passeatas organizadas pelo movimento estudantil tomavam as ruas do centro daquela cidade, gerando confrontos com as forças de repressão, cujo saldo eram pessoas presas, feridas ou mortas. É nesse contexto violento e obscuro que Olney São Paulo resolve filmar um longa-metragem composto de três episódios. Um deles tem como base para o roteiro o conto de sua autoria, "Manhã cinzenta", publicado em 1966, na coletânea $A$ antevéspera e o canto do sol. Os outros dois episódios não foram filmados, em decorrência da proibição pela Censura do filme, no ano seguinte.

O filme em questão é um média-metragem, de 21 minutos, realizado em película $35 \mathrm{~mm}$, preto e branco, no qual à encenação ficcional agregam-se cenas de passeatas e confrontos reais. Em uma das passeatas, o protagonista foi colocado por Olney entre os manifestantes para ser filmado discursando, o que se constitui numa quebra radical das fronteiras entre os gêneros que compõem o filme: a ficção e o documentário.

Embora tenha realizado vários trabalhos, Manhã cinzenta marcaria para sempre e de modo trágico o percurso do cineasta. Este "filmexplosão, revolucionário, desintegrador de signos", como o adjetivou Glauber Rocha em Revolução do Cinema novo (1981), levaria seu criador a ser incurso na Lei de Segurança Nacional como um indivíduo perigoso, desestabilizador da ordem e, em seguida, levou-o à prisão e à tortura, cujas sequelas comprometeram o corpo e as emoções de Olney. Depois de proibido pelo Serviço de Censura, negativos e cópias foram destruídos, restando apenas uma, escondida nos arquivos da cinemateca do Museu de Arte Moderna (RJ), a qual foi localizada em 1994, despertando o interesse de pesquisadores dos estudos intersemióticos/intermídias. Cumpre-nos informar que, apesar de sua trajetória trágica no Brasil, Manhã cinzenta teve sua importância reconhecida em outros países, uma vez que conquistou o prêmio de melhor média-metragem na XIX 
Semana Internacional de Mannheim, e foi premiado no Festival de Oberhausen, na Alemanha, em 1972.

No início do filme Manhã Cinzenta, durante a apresentação dos créditos iniciais, vemos imagens da rua, com uma sinalização de via - uma seta - apontando em direção ao espectador, a caminhada e a rotina de pessoas comuns, em algumas tomadas que remetem ao clássico curta-documentário Chuva (1929), de Joris Ivens e Mannus Franken. Mas, ao contrário deste, que contava com as modernas e harmônicas composições de Lou Lichtveld, esta cena no começo do média-metragem analisado acontece ao som da canção "Glória", que integra a Misa criolla, a qual versa: "Gloria a Dios / en las alturas // y en la tierra paz a los hombres, / [...] paz a los hombres / que ama El Señor [...]”. A Misa criolla foi composta pelo músico argentino Ariel Ramírez (1964), no que fora chamado, na Argentina, de boom do folclore. Nesse momento houve uma aproximação de músicos de diversas formações com a cultura popular latino-americana. Como disse Díaz (2004), houve, naquele momento, uma busca pela recuperação do latino-americano, como uma ideia de união cultural dos países da América Latina, sem que, com isso, houvesse um retrocesso com relação às particularidades de cada região. Essa obra, em específico, é uma peça que mescla elementos da música erudita e da tradição andina, numa intenção de re-leitura da tradição religiosa judaico-cristã.

A canção em questão inscreve-se duplamente irônica na cena de abertura, sublinhando o viés trágico-dramático das situações narradas dali em diante, pois a paz entre as pessoas é justamente aquilo que não foi celebrado naqueles momentos de repressão do Estado brasileiro. Por outro lado, nos recordamos do tipo de "paz" preconizada pelas manifestações de março de 1964, nas "Marchas da Família com Deus pela Liberdade", uma série de eventos públicos que representavam uma classe média - expressão do conservadorismo - temerosa de uma "ameaça comunista", propaganda alastrada pelos grandes sistemas de informação.

Vale lembrar que a ironia, como figura de linguagem, consiste em apontar o contrário do que está sendo dito ou mostrado, visando a denunciar uma determinada situação e causar uma reação no receptor, seja ele leitor, ouvinte, espectador. Em razão de sua natureza opositiva, a ironia desestabiliza as verdades tomadas como absolutas, desvelando o avesso de certos discursos, pondo a nu suas incongruências (HUTCHEON, 2000, p. 98).

Dentre as categorias nas quais se divide a ironia, encontra-se a ironia trágica ou dramática, à qual acabamos de nos referir. Este tipo de ironia está associado às situações que possuem um desfecho trágico e cujos elementos presentes na cena indiciam para o leitor/espectador tal desfecho (ARAGÃO, 2011). Lembramos que os filósofos existencialistas 
do século XIX, sobretudo Kierkegaard e Schopenhauer, lançaram mão deste tipo de ironia em seus escritos.

Os planos se alternam entre abertos, sugerindo certa normalidade na rotina da cidade, e outros planos mais fechados, que despertam interesse fazendo parecer um ambiente com elementos deslocados, os quais denunciam que há algo irregular em seu meio. Em uma sala de aula, jovens, protagonistas do filme, escutam uma canção de rock (símbolo da rebeldia e liberdade naqueles tempos); eles parecem apreensivos, e uma jovem dança. A câmera realiza um travelling da janela da sala e nos possibilita ver a enseada da praia de Botafogo, no Rio de Janeiro, e nesse movimento focaliza a moça que dança, aparentemente alheia ao mundo fora da sala e aos colegas presentes. A dança, entretanto, aponta sua potência e rebeldia com a expressão específica que o movimento do corpo ascende.

Ao mostrar a enseada pela janela, a saturação de luz sugere-nos a ocorrência de algo, enquanto os jovens estão na sala de aula. A cena muda para passeatas (reais) dos estudantes, da resistência ao golpe, há confronto. Em nova relação intermidiática, entra a marcha The Washington Post. Essa marcha foi composta por John Philip Sousa, compositor de várias outras marchas militares que, a pedido dos proprietários do jornal que leva o mesmo nome da marcha, fora contratado para compô-la; ele tivera tanto êxito que o jornal seria reconhecido por ela (BIERLEY, 1973). Vemos que novamente a música opera como elemento irônico, lembrando ao espectador o apoio dado pelos Estados Unidos ao golpe brasileiro.

Em outra relação intermidiática, ouvimos ao som da marcha militar "Semper Fidelis"7, também de John Philip Sousa, trechos dos Autos da Devassa - peça processual contra os inconfidentes mineiros do século XVIII, acusados de traição à coroa portuguesa. Em seguida, Sílvio, um dos protagonistas, realiza uma leitura do parágrafo final de A Peste, do filósofo argelino Albert Camus, que é uma alegoria do Nazismo e de todos os regimes de exceção. Em contraponto à marcha militar, são ouvidos trechos de É proibido proibir, de Caetano Veloso. Essa canção é significativa porque fora escrita em princípios do recrudescimento da violência do regime ditatorial, sendo um canto pela liberdade; demonstra-nos as sendas para a resistência. Estas são apontadas pela voz da canção que utiliza poeticamente do artifício da proibição, que é a arma simbólica dos regimes ditatoriais, como um elemento para criação do sentimento de que é necessário resistir, é necessário lutar pela liberdade. A canção ainda passou por um episódio interessante, tendo sido executada e vaiada no III Festival

\footnotetext{
${ }^{7}$ Composta no final do século XIX, essa marcha militar tem o nome que fora retirado do lema da Marinha estadunidense. Ela, por isso, foi adotada como um hino dessa instituição militar (BIERLEY, 1973).
} 
Internacional da Canção. Assim, a execução tornara-se uma espécie de confusão: Caetano em sua performance da canção fora vaiado pelo público, que negou o diálogo e deu-lhe as costas. Gilberto Gil, que participava da execução, foi atingido por um tomate, e em resposta apanhara-o do chão e o mordera. O desfecho do acontecimento foi o discurso desorientador de Caetano que incisivamente destacou, grosso modo, que a árvore da intolerância é uma só, sendo seus galhos a proibição do argumento do outro ou o cerceamento dos direitos cidadãos. Naquele momento, a crítica fora feita pelo público que via - sem perfazer uma análise contextual - nas guitarras elétricas dos Mutantes e suas dissonâncias uma aproximação possível com a política estadunidense.

No filme, novo relato, pelo rádio, de um massacre de trabalhadores, e na trilha sonora surgem mais uma vez os versos da Misa Criolla. A cena volta para as ruas como no início do filme, mas agora, ao invés de pessoas em suas rotinas, temos fumaça, violência e forte repressão policial. São cenas de confrontos reais e, assim como ao longo da obra, cenas deliberadamente encenadas se juntam a cenas documentárias, formando um retrato híbrido e potente daquele período brasileiro. Há uma simultaneidade de cenas e tempos, revezando-se a sala de aula do início do filme com as cenas de um quartel onde ocorrem torturas de jovens prisioneiros. Neste momento, ocorre uma metáfora imagética na cena em que aparece um cinema cercado de policiais e o cartaz do filme A noite dos generais (1967), de Anatole Litvak, exibido como crítica ao regime, em um cinema da Cinelândia, logo após o assassinato do estudante Edson Luís.

Sob uma frase musical do charango $^{8}$, aparece Sílvio dentro da sala de aula, demonstrando preocupação; logo muda-se para a cena em que ele desce a escadaria do quartel, a qual subira com Alda, a outra protagonista do filme. Na cena da tortura, o soldado lança a ele uma inquirição, já certo da resposta: "E as metralhadoras, não é certo que tinham metralhadoras?" A cena mostra a crueza e a violência da tortura.

Numa relação intermidiática, uma voz locutora no rádio, ao som de marcha militar, enuncia: "É na ressurreição das elites que se poderá desagregar o caos e edificar a justiça, estabelecer a ordem e por isso..." (SÃO PAULO, 1969, 12:10-12:22). Volta-se à mesma sala de aula do início do filme, os jovens conversam sobre a tortura, sobre o golpe, em um diálogo em que cada um vai complementando o outro, e que termina com a consideração de Sílvio:

\footnotetext{
${ }^{8}$ Um pequeno instrumento de cordas andino, tradicionalmente feito a partir da carapaça de Tatu (OXFORD, 2017).
} 
“[...] Ninguém é mais povo. Não se é mais nada, o povo será massacrado. Primeiro a bala, depois a fome, devagarzinho, tudo virá contra o povo..." (SÃO PAULO, 1969, 12:32-13:03).

Ao som de "Señor tiene piedad de nosotros", que integra a Misa criola, a montagem caleidoscópica do filme se concretiza mais uma vez. Mescla-se o fuzilamento de jovens, a sala de espera pós-tortura, em que uma jovem ensaia uma dança, e logo a cena volta para a sala de aula do início do filme. Os estudantes escutam a notícia sobre a repressão. Alda diz: “Canalhas! [...] Mas eles me encontrarão de pé!”, e inicia a dança que vimos no início do filme. Manhã cinzenta termina com o assassinato do casal Alda e Sílvio, ao som da canção "Credo", da Misa Criolla, em desejo que a esperança não morra com ele.

A proibição do filme é parte de um diálogo negado, o que não encerra as relações dialógicas estabelecidas nas malhas do texto fílmico, até porque a negação se deu justamente pelo fato de o filme trazer elementos intermidiáticos de revelação/apresentação/contestação do golpe em curso, elementos cuja montagem contribuiu para a construção de Manhã cinzenta como um contra-discurso ao autoritarismo, um contraponto entre a voz do Outro (os oprimidos, representados pelos estudantes e os trabalhadores) e a voz do Mesmo (os ditadores, empresários e a classe média).

\subsection{O músculo-música}

Observamos aqui a relação intersemiótica/intermidiática entre música e cinema em Manhã cinzenta. A música é tão poderosa como elemento artístico que sua junção com outras formas de arte muito comumente potencializa ambas, e exemplo claro disto é sua junção com o cinema, onde se destaca o "potencial sugestivo para enriquecer as suas estratégias narrativas" (BAPTISTA, 2007), e em que harmonias musicais sugerem emoções e espaços geográficos, além de conduzir o ritmo da edição e de ações nos planos.

A frase "O cinema nunca foi mudo" (BERCHMANS, 2006) nos faz refletir acerca de algo óbvio: por mais que em suas primeiras décadas de vida o cinema não pudesse emitir sons ambientes e de falas dos seus personagens, as sessões de exibição eram acompanhadas de músicas, normalmente tocadas ao vivo, mas também podendo ser ouvidas por reprodutores de som. Muitas vezes, essas músicas acompanhavam as sensações apresentadas nos filmes, mas com o tempo elas foram ficando mais sofisticadas, independentes, e agregaram seus sentidos próprios aos filmes, até chegar ao uso da música moderna, que, por vezes, acompanhava as próprias películas, como no exemplo anteriormente citado do curta-documentário Chuva, de Joris Ivens e Mannus Franken, com composição de Lou Lichtveld. Com o tempo, o que 
dominava o cinema era o uso da música como elemento que ajudava a criar o ilusionismo, tal qual no cinema Naturalista Hollywoodiano.

No momento da realização de Manhã cinzenta, o uso da música havia alcançado novos patamares, e o comum era a utilização de músicas populares cantadas nos filmes, como, por exemplo, a canção "The Sound of Silence", de Simon \& Garfunkel, no filme estadunidense The Graduate (1968), de Mike Nichols; ou as canções "Antônio das Mortes" e "Deus e o Diabo Na Terra Do Sol", ambas cantadas por Sérgio Ricardo, no filme homônimo de Glauber Rocha, onde foram empregadas com o mesmo senso não diegético.

Um dos maiores estudiosos sobre o uso da música no cinema é o escritor e compositor Michel Chion, e dentre suas análises a respeito do assunto podemos citar algumas que são aplicáveis diretamente ao média-metragem Manhã Cinzenta, no qual as músicas exercem inúmeras funções. Uma dessas funções é reiterar a mudança de ambiente e situação, como quando os créditos iniciais mostram o ambiente urbano ao som de "Gloria", de Ariel Ramírez e a música funciona como elemento extradiegético (produzida por uma fonte imaginária ausente da ação), ou como quando a cena corta para a sala de aula em que Alda está dançando ao som de uma canção de rock and roll, que é um elemento diegético (executado dentro da ação). Nesta última cena citada, temos o aparelho tempo/espaço em que a música que Alda dança no início do filme tem como um de seus sentidos situar o espectador em um período cultural específico, e, por extensão, caracterizar os jovens apresentados.

É ainda Michel Chion quem afirma:

Quem já montou filmes sabe que é difícil de traduzir visualmente, mesmo em plano geral, a amplidão de um cenário alpino, pela falta de referências precisas de escala e de linhas de fuga claras para o olhar. É aqui frequentemente que, nos documentários como em filmes de ficção, a música é chamada para salvar a cena: um acorde de cordas 'vazio' (como nos poemas sinfônicos de Richard Strauss ou de Vincent d'Indy) ou também uma escrita orquestral bem estendida pelos registros dos instrumentos vão possibilitar a tradução do espaço que a imagem não exprime [...]. Seguindo as análises, inúmeras combinações variadas ocorrem no filme, onde "se experimentarmos várias músicas - de estilos e/ou épocas diferentes e que representem códigos culturais distintos - sobre uma mesma cena, cada uma provocará como consequência uma leitura particular dessa cena. (CHION, 1995, p. 220 apud BAPTISTA, 2007, p. 28).

Em Manhã Cinzenta, a música tem também a intenção/função irônica - casos da utilização de "Gloria" e das marchas militares de John Philip Sousa. Com relação a isto, adentramos outra questão levantada por Chion, que é a da música como resumo do filme ou de cenas, onde músicas atribuem sentimento ou sentido às imagens, como as cenas em que trechos de É Proibido Proibir são tocados. 
Algo que é muito aparente no filme é o uso de valor agregado, termo citado por Chion em La musique au cinéma (1995), que é “[...] um efeito criado por um acréscimo de informação, de emoção, de atmosfera, conduzido por um efeito sonoro e espontaneamente projetado pelo espectador (o áudio-espectador, de fato) sobre o que ele vê, como se esse efeito emanasse naturalmente." (CHION, 1995, p. 220 apud BAPTISTA, 2007). Em Manhã cinzenta, seja com o rock da cena inicial, em que Alda dança, ou nas marchas de John Philip Sousa, as músicas agregam valor de sentido e de emoção às cenas, além de reforçarem ou criarem discursos, propiciando maior potência das imagens.

Quanto à fluidez estruturante do leitmotiv (conceito que advém das óperas de Wagner, que associa um certo tema musical a um papel na trama), Olney aplica sutis formas que marcam personagens ou discursos e ações dos mesmos, como os trechos da música de Caetano Veloso no média-metragem, que relaciona a canção aos momentos de Alda e Silvio e sublinham o engajamento político-social da juventude; as marchas de John Philip Sousa como metáforas/referências ao militarismo e à ditadura, ou a luta constante contra ela; e a Misa Criolla, que reflete o clamor da sociedade, seja por liberdade, seja por justiça, ou pela esperança, também podendo variar de significado em momentos que a montagem gera a ironia trágica.

\section{Conclusões: arremates finais}

Procurando superar os limites e as proibições do contexto político-social adverso, Olney São Paulo mobilizou um vigoroso exercício de linguagem para compor seu filme, lançando mão de artifícios variados para evidenciar os interditos, os silenciamentos impostos às produções artístico-culturais pela censura do regime militar. Um desses artifícios é a intermidialidade cinema-música, como procuramos mostrar aqui. Outro é a hibridização dos gêneros, a mescla entre ficção e documentário, que se transforma num eloquente entrelace sígnico, projetando-se contra o silêncio que pairava no contexto exterior (o Brasil dos anos da ditadura civil-militar). Cumpre-nos ainda informar que há muitos outros aspectos que caracterizam a obra do cineasta como uma "tessitura intermídia", os quais podem ser observados, por exemplo, nos recursos técnicos utilizados ou nas aproximações a outras estéticas cinematográficas, como o formalismo russo, o neorrealismo italiano e a nouvellevague francesa.

(Re)ver Manhã cinzenta é trazer para este momento, de ameaça à democracia no Brasil (e no mundo), reflexões sobre a História e a memória político-cultural de uma época de autoritarismo e repressão, importantes para entendermos o momento atual. Neste sentido, 
convém lembrar que o filme aqui analisado lançou o olhar não apenas para o contexto que lhe era contemporâneo, isto é, para as ditaduras brasileira e latino-americanas da década de 19601970, como também para a gênese das mesmas: Nazifacismo e guerra fria. Assim, ao entrelaçar arte e política, Olney São Paulo legou à posteridade não apenas um registro daquele momento, por meio do texto fílmico que analisamos, mas arrematou, dentro da tessitura intermídia do documentário ficcional, a noção de que os golpes, as ditaduras, podem sempre retornar, se as lembranças de sua opressão e violência forem apagadas da memória das sociedades.

\section{Referências}

ARAGÃO, Hudson Oliveira Fontes. Pequeno ensaio sobre a ironia. Disponível em: <https://goo.gl/eHQhWW>. Acesso em: 22 ago. 2017.

BAPTISTA, André. Funções da música no cinema: contribuições para a elaboração de estratégias composicionais. (Dissertação de Mestrado em Música) - Universidade Federal de Minas Gerais, Belo Horizonte, 2007.

BERCHMANS, Tony. A Música do Filme: tudo o que você gostaria de saber sobre música de cinema. São Paulo: Escrituras Editora, 2012.

BIERLEY, Paul E. John Philip Sousa: American Phenomenon. Miami: Warner Bros Publications, 1973.

BENJAMIN, Walter. Sobre o conceito de história. In: BENJAMIN, Walter. Obras escolhidas I- magia e técnica, arte e política. 7. ed. Tradução de Sergio Paulo Rouanet. Prefácio de Jeanne Marie Gagnebin. São Paulo: Brasiliense, 1994.

CHION, Michel. La musique au cinéma. Paris: Librairie Arthème e Fayard, 1995, p. 220, apud BAPTISTA, André. Funções da música no cinema: contribuições para a elaboração de estratégias composicionais. Dissertação (Mestrado em Música) - Universidade Federal de Minas Gerais, Belo Horizonte, 2007.

CLÜVER, Claus. Inter textus / Inter artes / Inter media. Tradução de Elcio Loureiro Cornelsen. Aletria: Revista de Estudos de Literatura, v. 14, p. 11-41, jul./dez. 2006.

DÍAZ, Claudio F. Una vanguardia en el folklore argentino: canciones populares, intelectuales y política en la emergencia del "Nuevo Cancionero". Mar del Plata: 2do. Congreso Nacional CELEHIS de Literatura. Disponível em: <http://www.mdp.edu.ar/humanidades/letras/celehis/congreso/2004/actas/ponencias/9/2_Diaz .doc>. Acesso 13 jun. 2018.

HUTCHEON, Linda. Teoria e política de ironia. Tradução de Julio Jeha. Belo Horizonte: Editora UFMG, 2000. 
LIVTAK, Anatole. A noite dos Generais [The night of the Generals]. França; Reino Unido; Irlanda do Norte. 1967.

NOVAES, Claudio Cledson. Reflexões sobre a escrita intersemiótica em A antevéspera, de Olney São Paulo. Estudos de Literatura Brasileira Contemporânea, n. 37. Brasília, p. 47-59, jan./jun. 2011.

OXFORD Dictionary. Oxford: University Press, 2017.

RAJEWSKY, Irina. A fronteira em discussão: o status problemático das fronteiras midiáticas no debate contemporâneo sobre intermidialidade. Traduzido por Isabella Santos Mundim. In: DINIZ, Thaïs Flores; VIEIRA, André Soares (Org.). Intermidialidade e estudos interartes: os desafios da arte contemporânea. Belo Horizonte: Rona; Fale/UFMG, 2012. p. 51-74.

RAMÍREZ, Ariel. Gloria (Carnavalito-Yaraví). In: RAMÍREZ, Ariel. Misa Criolla/Navidad Nuestra. Charango: Jaime Torres. Argentina: Philips, 1964.

RANCIÈRE, Jacques. Partilha do sensível: estética e política. Tradução de Mônica Costa Netto. São Paulo: EXO experimental org.; Ed. 34, 2005.

ROCHA, Glauber. Revolução do Cinema novo. Rio de Janeiro: Alhambra/EMBRAFILME, 1981.

SÃO PAULO, Olney Alberto. Manhã Cinzenta. Produção: Olney Alberto São Paulo e Ciro de Carvalho Leite. Fotografia: José Carlos Avelar. Brasil, 1969. 22min, P\&B, 35mm. Disponível em: <https://youtu.be/b6X65a16nxA>. Acesso em 20 nov. 2017.

SILVA, Vitor Manuel de Aguiar e. Teoria da literatura. 7. ed. Coimbra: Livraria Almedina, 1986.

SOUSA, John Philip. Semper Fidelis. 1888.

SOUSA, John Philip. The Washington Post. 1889.

VELOSO, Caetano. É proibido proibir. 1968.

WINGSTEDT, J. Narrative Music: Towards and Understanding of Musical. Narrative Functions in Multimedia. Apud BAPTISTA, André. Funções da música no cinema: contribuições para a elaboração de estratégias composicionais. Dissertação (Mestrado em Música) - Universidade Federal de Minas Gerais, Belo Horizonte, 2007.

WOLF, W. Intermediality. In: HERMAN, D.; RYAN, M. L. (Eds.). The Routledge Encyclopedia of Narrative Theory. London: Roudedge, 2005. 